\title{
ANALISIS PERLAKUAN AKUNTANSI ATAS PENDAPATAN DAN BIAYA PADA PT.SKYTECH INDONESIA
}

\author{
Lesli Mersi Goni \\ Jantje J. Tinangon \\ Stanley Kho Walandow \\ Fakultas Ekonomi dan Bisnis Jurusan Akuntansi \\ Universitas Sam Ratulangi Manado \\ Email : lesli_goni@yahoo.com
}

\begin{abstract}
ABSTRAK
Pendapatan merupakan salah satu unsur penting untuk memaksimalkan laba.

Pendapatan harus diukur secara wajar agar pendapatan yang akan diakui perusahaan tepat, sehingga terhindar dari overstate atau understate dalam penyajian pada laporan keuangan. Menurut PSAK No. 34 (revisi 2010), ada 2 metode pengakuan pendapatan yang digunakan yaitu metode persentase penyelesaian dan metode kontrak selesai. Tujuan penelitian ini adalah untuk mengetahui kesesuaian pengakuan pendapatan dan biaya oleh PT. Skytech Indonesia dengan PSAK No.34 (revisi 2010). Metode analisis yang digunakan adalah deskriptif kualitatif. Hasil penelitian mengungkapkan bahwa perusahaan menggunakan metode persentase penyelesaian dengan dasar biaya terhadap biaya dimana telah menunjukkan nilai yang wajar. Demikian pula dengan pengakuan dan pengukuran biaya yang terkait dengan pendapatan berdasarkan nilai wajar
\end{abstract}

.Kata kunci: Analisis, Pendapatan, Persentase Penyelesaian, Biaya.

\begin{abstract}
Income is one of the important elements to maximize the profits. Revenue should be measured appropriately so that the revenue will be recognized the right company, so avoid overstate or understate the presentation of the financial statements . According to PSAK No. . 34 ( revised 2010), there are two methods of revenue recognition method used is the percentage of completion and completed contract method. The purpose of this study was to determine the suitability of the recognition of revenue and expenses by PT. Skytech Indonesia with PSAK No. 34 ( revised 2010 ). The analytical method used is descriptive qualitative, where the data obtained, compiled, categorized, interpreted, and analyzed so as to give a proper picture. The results of the study revealed that the company uses the percentage of completion method on the basis of cost against the cost of which has shown a reasonable value . Similarly, the recognition and measurement of costs associated with the revenue based on the fair value .
\end{abstract}

Keywords : Analysis, Revenue, Percentage of Completion, Cost 


\section{PENDAHULUAN}

\section{Latar Belakang}

Dunia usaha yang semakin berkembang seiring dengan kemajuan zaman menuntut para pelaku bisnis untuk selalu tanggap terhadap segala perubahan yang terjadi. Kemajuan teknologi, informasi serta metode yang berhubungan dengan kondisi dalam suatu badan usaha sudah seharusnya menjadi bahan acuan bagi pihak manajemen perusahaan, baik perusahaan yang berskala besar maupun kecil untuk menghasilkan kinerja yang terbaik. Hal tersebut berhubungan erat dengan upaya penciptaan nilai yang baik dari suatu badan usaha kepada pihak luar.

Secara umum semua perusahaan baik itu perusahaan industri, dagang maupun jasa tentu memiliki tujuan sama yaitu memperoleh laba pada tingkat tertentu. Untuk memudahkan perusahaan dalam memperoleh laba, maka pihak manajemen perusahaan memerlukan informasi berkaitan dengan tujuan yang hendak dicapai serta diperlukan beberapa pengetahuan dan alat yang efektif. Salah satu pengetahuan dan alat yang dimaksud adalah akuntansi.

\section{Tujuan Penelitian}

Adapun tujuan yang ingin dicapai dalam penelitian ini sesuai dengan perumusan masalah diatas untuk mengetahui perlakuan akuntansi pendapatan dan biaya PT Skytech Indonesia apakah telah sesuai dengan Pernyataan Standar Akuntansi Keuangan No 34 (revisi 2010) tentang Kontrak Konstruksi.

\section{TINJAUAN PUSTAKA}

Pengertian akuntansi menurut (hongren \& Harrison, 2007:4) menyatakan bahwa "akuntansi adalah system informasi yang mengukur aktivitas bisnis,memproses data menjadi laporan, dan mengkomunikasikan hasilnya kepada para pengambil keputusan.” Menurut Komite American Institute Of Certified Public Accounting (AICPA) yang dikutip dari buku Harahap (2012:5) "akuntansi adalah seni pencatatan, penggolongan,pengiktisaran dengan cara tertentu dan dalam ukuran moneter, transaksi dan kejadian-kejadian yang umumnya bersifat keuangan dan termasuk menafsirkan hasil-hasilnya."

Menurut Kieso, Weygandt dan Warfield (2011) "laporan keuangan adalah sarana utama bagi perusahaan untuk mengkomunikasikan informasi keuangan kepada pihak luar." Menurut Lam \& Lau (2009) "laporan keuangan adalah representasi terstruktur atas posisi keuangan dan performa keuangan entitas. Dari semua pengertian laporan keuangan menurut para ahli ekonomi, penulis dapat menyimpulkan bahwa laporan keuangan adalah hasil dari proses akuntansi yang merupakan penghubung antara perusahaan dengan pihak yang berkepentingan dengan cara memberikan informasi yang bermanfaat bagi pihak tersebut untuk mengetahui keadaan dan perkembangan perusahaan bersangkutan."

Menurut Hery (2013:46) untuk menentukan besarnya jumlah pendapatan dan beban secara tepat pada periode yang tepat, ada dua pilihan yang tersedia yang dapat dijadikan sebagai dasar pencatatan oleh akuntan, yaitu:

1. Cash basis

2. Accrual basis

Menurut Harahap dalam buku Teori Akuntansi (edisi revisi 2011) (2012:242-243) menurut teori matching concept, maka biaya harus dibebankan sesuai dengan pengakuan dan periode penghasilan. berikut:

Berdasarkan waktu pengeluaran atau pembebanan biaya dan prinsip matching dikenal dua konsep sebagai

1. Direct atau produk matching

2. Indirect atau period matching

\section{Pengertian Pendapatan}

Menurut Sodikin \& Riyono (2012:91) yang dikutip dari SAK ETAP 2009 paragraf 2.20a mendefinisikan pendapatan yaitu, "penghasilan atau (income) adalah kenaikan manfaat ekonomi selama periode pelaporan dalam bentuk arus masuk atau peningkatan asset, atau penurunan kewajiban yang mengakibatkan kenaikan ekuitas yang tidak berasal dari kontribusi penanaman modal.” 
Menurut PSAK No. 34 revisi 2010 paragraf 11 mendefinisikan, pendapatan kontrak terdiri dari :

1. Nilai pendapatan semula yang disetujui dalam kontrak, dan;

2. Penyimpangan pekerjaan kontrak, klaim dan pembayaran insentif :

a. Sepanjang hal ini memungkinkan untuk menghasilkan pendapatan, dan;

b. Dapat diukur secara andal.

\section{Pengakuan Pendapatan}

Menurut (Donald Kieso, et al. 2008:515) "prinsip pengakuan pendapatan (revenue recognitioan principle) menetapkan bahwa pendapatan diakui pada saat:

1. Pendapatan direalisasi apabila barang dan jasa ditukar dengan kas atau klaim atas kas (piutang).

2. Pendapatan dapat direalisasi apabila aktiva yang diterima dalam pertukaran segera dapat dikonversi menjadi kas atau klaim atas kas dengan jumlah yang diketahui.

3. Pendapatan dihasilkan (earned) apabila entitas bersangkutan pada hakikatnya telah menyelesaikan apa yang seharusnya dilakukan untuk mendapat hak atas manfaat yang dimiliki oleh pendapatan itu, yakni, apabila proses menghasilkan laba telah selesai atau sebenarnya telah selesai.

\section{Pengakuan Pendapatan Sebelum Penyerahan}

Menurut (Donald Kieso, et al. 2008:521-527), ada 2 metode metode akuntansi yang sangat berbeda untuk kontrak konstruksi jangka panjang yang diakui oleh profesi akuntansi:

1. Metode persentase penyelesaian (percentage of completion method)

Untuk menerapkan metode persentase penyelesaian, perusahaan harus mempunyai beberapa dasar atau standar untuk mengukur kemajuan kea rah penyelesaian pada tanggal interim tertentu. Metode yang paling umum digunakan adalah metode biaya terhadap biaya (cost-to-cost-method) dan metode unit yang dikirimkan (units delivery method).

2. Metode kontrak selesai (completed contract method

Pendapatan dan laba kotor hanya diakui pada saat penjualan yaitu, pada saat kontrak diselesaikan. Menurut metode ini perusahaan mengakumulasi biaya kontrak jangka panjang dalam proses, tetapi tidak ada pembebanan dan pengkreditan interim keakun laporan laba rugi seperti pendapatan, laba dan laba kotor.

3. Dasar penyelesaian produksi

Menurut Dasar Penyelesaian Produksi, pendapatan diakui pada saat logam ditambang atau produk pertanian dipanen karena harga jualnya dapat dipastikan dengan layak, unit-unitnya dapat dipertukarkan, serta tidak diperlukan biaya yang signifikan dalam mendistribusikan produk itu.

\section{Pengakuan Pendapatan Setelah Penyerahan}

Menurut (Donald Kieso, et al. 2008:533) ada 2 metode yang biasanya dipakai untuk menangguhkan pengakuan pendapatan sampai kas diterima yaitu

1. Metode Akuntansi Penjualan Cicilan

2. Metode Simpanan

\section{Pengukuran Pendapatan}

Pengukuran ialah pemberian nilai dan atribut-atribut pengukuran akuntansi pada item tertentu dari suatu transaksi berdasarkan satuan ukuran uang. Pendapatan harus diukur dengan nilai wajar imbalan yang diterima atau yang dapat diterima. Nilai wajar adalah suatu jumlah, untuk itu suatu aktiva mungkin ditukar atau suatu kewajiban diselesaikan dengan pihak yang memahami dan berkeinginan untuk melakukan transaksi wajar.

\section{Pengertian Biaya}

Harahap (2012:244) yang dikutip dari FASB mendefinisikan biaya yaitu”expense sebagai arus keluar aktiva, penggunaan aktiva atau munculnya kewajiban atau kombinasi keduanya selam suatu periode yang disebabkan oleh pengiriman barang, pembuatan barang, pembebanan jasa atau pelaksanaan kegiatan lainnya yang merupakan kegiatan utama perusahaan." 
Biasanya biaya dibagi dalam 3 golongan yaitu:

1. Biaya yang dihubungkan dengan penghasilan pada periode itu;

2. Biaya yang dihubungkan dengan periode tertentu yang tidak dikaitkan dengan penghasilan;

3. Biaya yang karena alas an praktis tidak dapat dikaitkan dengan periode manapun.

\section{Pengukuran Biaya}

Pengukuran merupakan penambahan kewajiban dan deplesi aset di periode berjalan mungkin tampak tugas sederhana. Ada beberapa standar akuntansi yang memberikan panduan mengenai hal-hal seperti itu, tapi menawarkan pilihan dalam metode biaya dan pembagian pendapatan. Sebagai contoh, IAS 16/AASB 116 aset, dan tetap memungkinkan untuk nilai aset tetap menjadi masured dalam beberapa cara setelah pengakuan (misalnya model biaya atau model penilaian) dan beberapa pilihan penyusutan alternatif (misalnya garis lurus, nilai berkurang dan unit metode produksi).

\section{Pengakuan Biaya}

Chariri dalam Mulia (2007) menyatakan bahwa pengukuran pendapatan dapat didasarkan pada historical cost, replacement cost . Pada umumnya pengukuran biaya atau beban menggunakan metode historical cost lebih sering digunakan yaitu pengukuran beban berdasarkan jumlah rupiah yang dikeluarkan pada saat barang dan jasa diperoleh. Pada dasarnya cost memiliki dua kedudukan penting, yaitu :

1. sebagai aktiva (potensi jasa)

2. sebagai beban pendapatan (biaya)

\section{Pendapatan Kontrak Menurut PSAK No. 34 (Revisi 2010) Kontrak Konstruksi}

Kontrak konstruksi meliputi:

1. kontrak pemberian jasa yang berhubungan langsung dengan konstruksi aset, misalnya, pelayanan jasa untuk manajer proyek dan arsitek; dan

kontrak untuk penghancuran atau restorasi aset dan restorasi lingkungan setelah penghancuran aset.

\section{Pendapatan Kontrak}

Pendapatan kontrak terdiri dari:

1. Nilai pendapatan semula yang disetujui dalam kontrak

2. Penyimpangan dalam pekerjaan kontrak, klaim, dan pembayaran insentif:

a. Sepanjang hal ini memungkinkan untuk menghasilkan pendapatan;

b. Dapat diukur secara andal.

\section{Pengukuran Pendapatan}

Pendapatan kontrak diukur pada nilai wajar dari imbalan yang diterima atau akan diterima. Pengukuran pendapatan kontrak dipengaruhi oleh beragam ketidakpastian yang bergantung pada hasil dari peristiwa di masa depan. Estimasi sering kali perlu untuk direvisi sesuai dengan realisasi dan hilangnya ketidakpastian. Oleh karena itu, jumlah pendapatan kontrak dapat meningkat atau menurun dari satu periode ke periode berikutnya. Misalnya:

1. Kontraktor dan pelanggan mungkin menyetujui penyimpangan atau klaim yang meningkatkan atau menurunkan pendapatan kontrak pada periode setelah periode di mana kontrak pertama kali disetujui;

2. Nilai pendapatan yang disetujui dalam kontrak dengan nilai tetap dapat meningkat karena ketentuanketentuan kenaikan biaya;

3. Nilai pendapatan kontrak dapat menurun karena denda yang timbul akibat keterlambatan kontraktor dalam penyelesaian kontrak tersebut

4. Jika dalam kontrak harga tetap terdapat harga tetap per unit ouput, pendapatan kontrak meningkat jika jumlah unit meningkat.

\section{Biaya Kontrak}

Biaya suatu kontrak konstruksi terdiri dari:

1. Biaya yang berhubungan langsung dengan kontrak tertentu; 
2. Biaya yang dapat diatribusikan pada aktivitas kontrak secara umum dan dapat dialokasikan pada kontrak tersebut; dan

3. Biaya lain yang secara khusus dapat ditagihkan ke pelanggan sesuai isi kontrak.

\section{Pengakuan Pendapatan Dan Beban Kontrak}

Pengakuan pendapatan dan beban dengan memerhatikan tahap penyelesaian suatu kontrak sering disebut sebagai metode persentase penyelesaian. Menurut metode ini, pendapatan kontrak dihubungkan dengan biaya kontrak yang terjadi dalam mencapai tahap penyelesaian tersebut, sehingga pendapatan, beban, dan laba yang dilaporkan dapat diatribusikan menurut penyelesaian pekerjaan secara proporsional. Metode ini memberikan informasi yang berguna mengenai cakupan aktivitas kontrak dan kinerja selama suatu periode. Dalam metode persentase penyelesaian, pendapatan kontrak diakui sebagai pendapatan dalam laba rugi pada periode akuntansi di mana pekerjaan dilakukan. Biaya kontrak biasanya diakui sebagai beban dalam laba rugi pada periode akuntansi di mana pekerjaan yang berhubungan dilakukan. Namun, setiap ekspektasi selisih lebih total biaya kontrak terhadap total pendapatan kontrak segera diakui sebagai beban.

\section{Pengakuan Taksiran Rugi}

Jika kemungkinan besar terjadi bahwa total biaya kontrak akan melebihi total pendapatan kontrak, maka taksiran rugi segera diakui sebagai beban. Jumlah kerugian tersebut ditentukan tanpa memerhatikan:

1. Apakah pekerjaan kontrak telah dilaksanakan atau belum;

2. Tahap penyelesaian aktivitas kontrak; atau

3. Jumlah ekspektasi laba yang akan diperoleh pada kontrak lain yang tidak diperlakukan sebagai satu proyek tunggal konstruksi

\section{Perubahan Estimasi}

Metode persentase penyelesaian diterapkan secara kumulatif dalam setiap periode akuntansi terhadap estimasi pendapatan kontrak dan biaya kontrak. Oleh karena itu, pengaruh perubahan dalam estimasi pendapatan kontrak atau biaya kontrak, atau pengaruh perubahan estimasi dari hasil kontrak, dipertanggungjawabkan sebagai perubahan dalam estimasi akuntansi (lihat PSAK 25 (revisi 2009): "Kebijakan Akuntansi, Perubahan Estimasi Akuntansi, dan Kesalahan)." Perubahan estimasi digunakan sebagai dasar dalam penentuan jumlah pendapatan dan beban yang diakui dalam laba rugi pada periode saat perubahan tersebut terjadi dan periode selanjutnya.

\section{Pengungkapan}

Entitas mengungkapkan:

1. Jumlah pendapatan kontrak yang diakui sebagai pendapatan pada periode;

2. Metode yang digunakan untuk menentukan pendapatan kontrak yang diakui pada periode;

3. Metode yang digunakan untuk menentukan tahap penyelesaian kontrak.

\section{METODE PENELITIAN}

Penulis menggunakan jenis metode penelitian deskriptif kualitatif. Penelitian dilakukan pada kondisi yang alamiah langsung ke sumber data, pengumpulan data menggunakan instrument penelitian, dan data yang terkumpul berupa sejarah perusahaan, visi dan misi perusahaan, struktur organisasi, aktivitas usaha perusahaan serta laporan laba rugi PT. Skytech Indonesia

\section{Tempat dan Waktu Penelitian}

Tempat penelitian dilakukan langsung pada PT.Skytech Indonesia yang berlokasi di Cibinong, Bogor, Jawa Barat. Waktu penelitian dilakukan selama 5 bulan yaitu mulai dari bulan Agustus sampai Bulan Desember tahun 2013.

Metode Pengumpulan Data Jenis data yang digunakan dalam penelitian ini adalah data kualitatif dan kuantitatif. Data kualitatif dalam penelitian ini adalah gambaran umum tentang perusahaan yang berupa sejarah perusahaan, visi dan misi perusahaan, struktur organisasi perusahaan, aktivitas usaha perusahaan. Sedangkan data 
kuantitatif dalam penelitian ini berupa laporan laba rugi PT. Skytech Indonesia pada proyek pekerjaan Listrik Ciwandan

Jenis Data

Secara umum data diartikan sebagai suatu fakta yang digambarkan lewat angka, dan tulisan yang merupakan keterangan atau sumber informasi mengenai objek yang akan diteliti dan sebagai dasar dalam pengambilan keputusan. Indriantoro \& Supomo (2002:145) mengungkapkan bahwa data penelitian pada dasarnya dapat dikelompokan menjadi tiga jenis yaitu: Data Subjek, Data Fisik, Data Dokumenter.

\section{Teknik Pengumpulan Data}

Untuk memperoleh data yang berhubungan dengan penelitian ini, maka metode pengumpulan data yang digunakan adalah sebagai berikut

1. Observasi

2. Wawancara

3. Studi kepustakaan

4. Dokumentasi

\section{Metode Analisis}

Metode analisis yang digunakan dalam penelitian ini adalah metode kualitatif deskriptif. Yaitu suatu metode pembahasan permasalahan yang sifatnya menguraikan, menggambarkan, membandingkan dan menerangkan suatu data atau keadaan secara terperinci mengenai suatu keadaan suatu badan usaha berdasarkan data atau informasi yang diperoleh dan dikumpulkan sehingga dapat dianalisa dan ditarik kesimpulan untuk mencapai tujuan yang ditetapkan.

\section{Sejarah PT. Skytech Indonesia}

PT Skytech Indonesia berdiri pada tahun 2008, yang berlokasi di Jakarta Barat oleh Bapak Edo Goni. PT Skytech Indonesia adalah perusahaan yang bergerak dibidang jasa konstruksi, khususnya dibidang industrial proses control, instrumentation dan networking. beralamat lengkap di Ruko Graha Pinus Blok B No 1, Jln Alternative Sentul, Bogor, Jawa Barat, 16710. Tel. +6221 - 82562227 Fax. +6221 - 82562226. Email : info@skytech-indonesia.co.id. Website : www.skytech-indonesia.co.id

\section{Visi dan Misi PT. Skytech Indonesia}

Visi PT Skytech Indonesia adalah menjadi pemimpin perusahaan kelas dunia dengan pelayanan solusi total untuk perdagangan, teknik mesin dan konstruksi yang memperhatikan kualitas dari produktivitas industri.

Adapun Misi dari perusahaan PT Skytch Indonesia adalah manajemen dan karyawan di semua level dalam organisasi memiliki berkomitmen menjalankan bisnis untuk menyediakan atau memberikan pelayanan terbaik dari teknik mesin ,pembuatan, dan konstruksi dari bangunan semen, kekuatan bangunan dan lain-lain untuk para pelanggan yang dapat menghasilkan nilai semua pemilik perusahaan.

\section{Hasil Penelitian}

Pengakuan Pendapatan Kontrak PT. Skytech Indonesia Perusahaan mengakui pendapatan berdasarkan tingkat kemajuan proyek yang diselesaikan. Pengakuan pendapatan ini diterapkan untuk semua kontrak konstruksi, baik yang berjangka waktu satu tahun atau yang berjangka waktu lebih dari satu tahun. Salah satu proyek yang dikerjakan adalah proyek proyek pekerjaan Listrik di Ciwandan. Untuk mengetahui persentase tingkat kemajuan pekerjaan proyek yang telah dicapai, perusahaan menentukannya berdasarkan tingkat kemajuan fisik pekerjaan yang telah diselesaikan dan kemudian dibandingkan dengan pekerjaan yang harus dikerjakan secara keseluruhan. Adapun pencapaian penyelesaian konstruksi yang dapat dicapai oleh perusahaan sebagai berikut : 
Tabel 4.1 Perhitungan Persentase Penyelesaian

\begin{tabular}{|l|}
\hline Biaya yang terjadi sampai tanggal ini $=$ persentase penyelesaian \\
Estimasi total biaya terkini $\quad=58.43 \%$ \\
Rp. 61.361 .900 \\
Rp. 105.000 .000
\end{tabular}

Sumber : Data Olahan

Dimana termin atau kas yang diterima oleh perusahaan sampai akhir Juni hanya sebesar 50\% atau Rp. 85.000.000, dari total yang harusnya diterima oleh perusahaan sesuai dengan kontrak yang telah di tandatangani yaitu sesuai dengan total pekerjaan yang telah diselesaikan sebesar $58.43 \%$ atau sebesar Rp. 99.347.383, yang artinya perusahaan mengakui laba terlalu rendah di bulan Juni, dan sebaliknya mengakui laba terlalu tinggi di bulan Juli. Dalam mengukur tingkat kemajuan penyelesaian pekerjaan, perusahaan menggunakan ukuran masukan yaitu berdasarkan jumlah biaya yang dikeluarkan untuk penyelesaian proyek tersebut. Pengukuran Pendapatan Kontrak PT. Skytech Indonesia, PT. Skytech Indonesia menggunakan nilai wajar dari imbalan yang akan diterima sebagai ukuran dalam penentuan pendapatan yaitu sebesar nilai kontrak yang telah disepakati bersama dalam surat kontrak antara pihak pemberi kerja dan pihak perusahaan. PT. Skytech Indonesia tidak melakukan pendiskontoan atas nilai tunai transaksi yang diterima atau yang akan diterma di masa yang akan datang. Pengukuran tingkat kemajuan pekerjaan dilakukan berdasarkan jumlah biaya yang dikeluarkan dalam penyelesaian proyek tersebut, tetapi juga berdasarkan taksiran oleh bagian teknik dari perusahaan yang diawasi oleh pengawas lapangan dari pihak pemberi kerja. Hasil dari pengukuran yang telah dibuat oleh pihak perusahaan, dibuat dalam bentuk Progress Report Activity, yang kemudian diperiksa dan ditanda tangani oleh konsultan teknik dari pihak pemberi kerja.

\section{Penerapan PSAK No.34 (revisi 2010) dalam Pengakuan dan Pengukuran Pendapatan Kontrak}

Pengakuan pendapatan ada dua metode yang dapat digunakan yaitu metode presentase penyelesaian. Dari penelitian yang dilakukan, diketahui PT. Skytech Indonesia dalam pengakuan pendapatannya menggunakan metode persentase penyelesaian baik untuk kontrak jangka panjang maupun kontrak jangka pendek. Dalam PSAK No.34 (revisi 2010) metode yang diterapkan oleh perusahaan dapat digunakan dalam pengakuan pendapatan oleh perusahaan sebagai perusahaan konstruksi. Metode persentase penyelesaian ada dua metode yang dapat digunakan untuk mengukur berapa besar kemajuan pekerjaan konstruksi yang dicapai, yaitu metode biaya terhadap biaya (cost to cost method) dengan menggunakan ukuran masukan yaitu menghitung besarnya persentase pekerjaan yang diselesaikan berdasarkan biaya yang terjadi sampai saat ini kemudian dibandingkan dengan total estimasi biaya secara keseluruhan sampai pekerjaan selesai, dan metode unit yang dikirimkan (units delivery method) dengan menggunakan ukuran keluaran yaitu menghitung besarnya presentase penyelesaian pekerjaan konstruksi berdasarkan taksiran tenaga ahli, dalam hal ini tenaga teknik untuk menilai kemajuan pekerjaan yang telah dicapai. Dalam PSAK No.34 (revisi 2010) mengakui metode unit yang dikirimkan (units delivery method) dengan menggunakan ukuran keluaran yang digunakan oleh perusahaan dalam mengukur besarnya presentase penyelesaian yang dicapai dalam pekerjaan konstruksi (proyek). Perusahaan mengukur besarnya pendapatan kontrak yang diakui menggunakan nilai wajar dari imbalan yang akan diterima sebagai ukuran untuk mengakui pendapatan. PSAK No.34 (revisi 2010) mengakui ukuran yang digunakan oleh perusahaan dalam mengakui pendapatan.

\section{Pembahasan}

\section{Analisis Pengakuan Pendapatan Kontrak}

Melalui laporan laba rugi proyek pekerjaan listrik ciwandan dapat diketahui PT. Skytech Indonesia dalam pengakuan pendapatannya adalah berdasarkan metode persentase penyelesaian (percentage of completed method), yaitu dimana perusahaan mengakui adanya pendapatan berdasarkan tingkat kemajuan pekerjaan yang diselesaikan, apabila proyek yang telah diselesaikan telah mencapai persentase tertentu sesuai dengan ketentuan dalam surat kontrak yang telah ditandatangani oleh kedua belah pihak, maka perusahaan akan mengirimkan tagihan dalam bentuk invoice kepada pihak pemberi kerja, dan perusahaan akan mengakui pendapatan apabila perusahaan sudah menerima pembayaran dari pihak pemberi kerja berdasarkan tingkat kemajuan pekerjaan yang telah diselesaikan oleh perusahaan. Metode pengakuan pendapatan ini diterapkan oleh perusahaan dalam kontrak yang berjangka waktu satu tahun dan juga kontrak yang berjangka waktu lebih dari satu tahun. Untuk kontrak yang pekerjaan 
konstruksinya berjangka waktu satu tahun, perusahaan akan lebih mudah untuk menentukan pendapatan yang diakui karena pekerjaan yang dilakukan berada dalam satu periode akuntansi. Sedangkan untuk kontrak yang pekerjaan konstruksinya berjangka waktu lebih dari satu tahun atau pekerjaan yang dilakukan pada dua periode akuntansi diperlukan estimasi yang tepat dalam menghitung besarnya pendapatan yang dapat diakui pada satu periode akuntansi meskipun pekerjaan konstruksi masih sementara berlangsung. Dalam metode persentase penyelesaian seperti yang sudah dibahas sebelumnya ada dua ukuran yang dapat digunakan yaitu ukuran masukan dan ukuran keluaran. Ukuran masukan dibuat sesuai dengan upaya yang dicurahkan dalam suatu kontrak, seperti biaya yang terjadi dan jam kerja. Sedangkan ukuran keluaran pada umumnya dibuat oleh seorang ahli teknik melalui metode taksiran teknik dengan menghitung volume fisik pekerjaan yang diselesaikan yang disajikan dalam bentuk laporan yaitu laporan prestasi fisik proyek. Perusahaan akan menerima pembayaran dari pihak pemberi kerja berdasarkan tata cara pembayaran sesuai dengan ketentuan dalam kontrak kerja dimana perusahaan akan menerima pembayaran berdasarkan persentase pekerjaan yang diselesaikan sesuai dengan termin pembayaran.

\section{Analisis Pengukuran Pendapatan Kontrak}

Pengujuran pendapatan oleh PT. Skytech Indonesia, berdasarkan nilai kas yang diterima pada saat terjadi transaksi. Untuk jumlah pendapatan yang timbul dari transaksi biasanya ditentukan oleh persetujuan antara perusahaan dengan pihak pemberi kerja. Dari sudut pandang akuntansi, pengukuran pendapatan ini dapat diterima karena perusahaan menggunakan ukuran pendapatan berdasarkan nilai wajar imbalan, dalam hal ini imbalan tersebut berbentuk kas yang akan diterima oleh perusahaan. Walaupun tanpa pendiskontoan, apabila harga kontrak yang disetujui telah digabungkan dengan tingkat bunga, dalam hal ini, berarti perusahaan menganggap bahwa tingkat bunga tidak berpengaruh banyak terhadap nilai uang yang diterima.

\section{Analisis Penerapan PSAK No.34 (revisi 2010) dalam Pengakuan dan Pengukuran Pendapatan Kontrak}

Sesuai dengan Pernyataan Standar Akuntasi Keuangan tentang pengakuan pendapatan, meyatakan bahwa pendapatan dapat diakui pada saat direalisasi atau dapat direalisasi dan dihasilkan. Penelitian yang telah dilakukan pada Skytech Indonesia menunjukkan bahwa perusahaan mengakui pendapatannya pada saat pekerjaan konstruksi selesai dengan persentase penyelesaian fisik yang dicapai. Hal ini menunjukkan bahwa perusahaan mengakui pendapatannya pada saat direalisasi yaitu pada saat jasa yang diberikan oleh perusahaan ditukar dengan kas atau piutang dari pihak pemberi kerja. Dengan demikian kriteria pengakuan pendapatan ini telah sesuai dengan Standar Akuntansi Keuangan. PSAK No.34 (revisi 2010) menyatakan bahwa ada dua metode dalam pengakuan pendapatan yaitu metode presentase penyelesaian dan metode kontrak selesai. Dari penelitian yang telah dilakukan, dalam pengakuan pendapatannya PT. Skytech Indonesia menggunakan metode persentase penyelesaian dimana pendapatan dan laba kotor diakui pada setiap periode berdasarkan kemajuan proses konstruksi. Metode presentase penyelesaian terbagi atas dua metode yaitu metode biaya terhadap biaya (cost to cost method) dan metode unit yang dikirimkan. Pada dasarnya metode biaya terhadap biaya menggunakan ukuran masukan untuk mengakui pendapatannya, sedangkan metode unit yang dikirimkan menggunakan ukuran keluaran. PT. Skytech Indonesia sendiri menggunakan ukuran masukan dalam menentukan besarnya pendapatan yang diakui yaitu berdasarkan persentase kemajuan fisik pekerjaan dikalikan dengan nilai kontrak untuk suatu proyek. Metode pengakuan pendapatan yang diterapkan oleh perusahaan ini telah sesuai dengan PSAK No.34 (revisi 2010). PSAK No.34 (revisi 2010) menyatakan bahwa pendapatan kontrak diukur pada nilai wajar dari imbalan yang diterima atau akan diterima. 
Tabel 4.15 Perbandingan Laba menurut PT. Skytech Indonesia dan menurut PSAK No.34 Revisi 2010

\begin{tabular}{|l|l|l|l|}
\hline \multicolumn{1}{|c|}{ Menurut perusahaan } & \multicolumn{1}{c|}{ Juni } & \multicolumn{1}{c|}{ Juli } & Total \\
\hline Pendapatan & Rp. 93.500 .000 & Rp.76.500.000 & Rp. 170.000.000 \\
\hline Biaya & Rp. 61.361.900 & Rp. 42.597.430 & Rp. 103.959.330 \\
\hline Laba Kotor & Rp. 23.138 .100 & Rp. 33.902.570 & Rp. 64.040.670 \\
\hline $\begin{array}{l}\text { Menurut PSAK No.34 } \\
\text { (revisi 2010) }\end{array}$ & \multicolumn{1}{c|}{ Juni } & Juli & Total \\
\hline Pendapatan & Rp. 99.347.838 & Rp. 70.652.162 & Rp. 170.000.000 \\
\hline Biaya & Rp. 61.361.900 & Rp. 42.597.430 & Rp. 103.959.330 \\
\hline Laba Kotor & Rp. 37.985.938 & Rp. 31.359.600 & Rp. 66.040.670 \\
\hline
\end{tabular}

Sumber : Data Olahan

Dalam pengukuran pendapatan yang diterapkan PT. Skytech Indonesi aadalah berdasarkan nilai kontrak yang disepakati dalam kontrak kerja. Hal ini menunjukkan bahwa pendapatan jasa konstruksi pada perusahaan ini diukur sebesar nilai wajar dari imbalan atas jasa yang diberikan oleh perusahaan kepada pihak pemberi kerja. Dengan demikian pengukuran pendapatan yang diterapkan oleh perusahaan ini telah sesuai dengan PSAK No.34 (revisi 2010).

\section{Analisis Perhitungan Pajak}

Perhitungan perpajakan oleh PT. Skytech Indonesia untuk pekerjaan kontrak konstruksi ada 2 yaitu Pajak Pertambahan Nilai (PPN) dan PPh pasal 23. Apabila proyek tersebut telah dikenakan PPN, maka dalam perhitungan PPh Pasal 23 tidak akan dihitung kembali karena bersifat Final. Dalam hal ini berkaitan dengan proyek yang dianalisa (proyek Pekerjaan Listrik di Ciwandan) pajak yang dikenakan adalah PPN yaitu sebesar 10\% dari total termin pembayaran atau uang kas yang diterima.

\section{PENUTUP}

\section{Kesimpulan}

1. Dalam mengakui pendapatan dan Biaya pada PT. Skytech Indonesia telah menggunakan Standar Akuntansi Keuangan yang berlaku di Indonesia yang mengatur perusahaan yang bergerak dibidang kontrak konstruksi (teknik) yaitu PSAK No. 34 (revisi 2010) tentang Kontrak Konstruksi, yaitu perusahaan telah menggunakan metode Persentase penyelesaian (percentage of completion method) dengan menggunakan metode biaya terhadap biaya baik proyek jangka pendek maupun jangka panjang, dimana dengan menggunakan metode ini dapat memperlihatkan hubungan langsung antara pendapatan dan biaya yang menghasilkan pendapatan tersebut.

2. Dengan adanya Cost Project yang dibuat oleh perusahaan untuk setiap proyek yang dilaksanakan perusahaan, pencatatan biaya yang dilakukan oleh perusahaan sudah tepat dan handal, sehingga dalam mengakui pendapatan dalam Laporan Laba Rugi PT. Skytech Indonesia dapat dihitung secara tepat dan terhindar dari Overstate maupun Understate.

3. Penagihan pendapatan dari pemberi kerja dilakukan sesuai dengan kontrak yang telah disepakati oleh pihak pemberi kerja dan PT. Skytech Indonesia, begitupun dengan pembayaran yang dilakukan oleh PT. Skytech Indonesia kepada Supplier dilakukan sesuai dengan kontrak yang ditandatangani bersama. 
1. PT. Skytech Indonesia mengakui dan menerapkan metode persentase penyelesaian berdasarkan kemajuan fisik dalam mengakui pendapatannya. Persentase penyelesaian berdasarkan pada estimasi kemajuan fisik atas pekerjaan yang telah dicapai di lapangan. Estimasi kemajuan fisik ini dituangkan dalam Laporan Prestasi Poyek yang dibuat petugas pengawas lapangan. Metode yang diterapkan ini mempunyai beberapa kelemahan, yaitu Taksiran penyelesaian kemajuan fisik yang dilakukan berdasarkan opname lapangan, tidak menjamin keakuratan penilaian dan dalam metode ini biaya yang terjadi tidak dapat diatribusikan pada tahap penyelesaian pekerjaan proyek dalam mengakui pendapatan periode berjalan, yang menyebabkan pendapatan, beban dan laba konstruksi yang dilaporkan tidak dapat diatribusikan menurut penyelesaian pekerjaan kontrak secara proporsional.

2. Penerapan metode persentase penyelesaian dengan dasar biaya terhadap Biaya oleh PT. Skytech Indonesia sudah baik. Hal ini dapat dilihat dengan adanya Cost Project yang di buat oleh perusahaan untuk mencatat biaya yang terkait langsung dengan proyek tersebut, tetapi dalam pembuatan cost project sebaiknya dibuat oleh pengawas lapangan agar pencatatannya lebih jelas

\section{DAFTAR PUSTAKA}

Harahap, Sofyan Syafir. 2005. Teori Akuntansi. Edisi Revisi. Penerbit Rajawali Pers. Jakarta.

Harahap. 2012. Teori akuntansi. Edisi Revisi 2011. Penerbit Rajawali Pers. Jakarta Horngren, Charles T. 2006. Akuntansi. Edisi Keenam. Jilid 1. Penerbit Indeks. Jakarta.

Nilam. 2012. Analisis Akuntansi atas Pendapatan Dan Biaya pada PT Cahaya Bangun Energi. Samarinda

Kieso, Donald E.,Weygant, Jerry J., Warfield, Terry D. 2010. Akuntansi Intermediate. Terjemahan. Edisi Kesepuluh. Penerbit Erlangga. Jakarta.

Slamet Sugiri Sodikin,Bogat A.Riyono. 2012. Akuntansi pengantar 1. Penerbit UPP STIM YKPN. Jakarta

Dr. (cand) Hery.2013.teori akuntansi suatu pengantar.lembaga Penerbit Fakultas Ekonomi Universitas Indonesia. Jakarta

Ikatan Akuntan Indonesia, 2009. Exposure Draft Pernyataan Standar Akuntansi Keuangan No. 23 (revisi 2009) "Pendapatan". IAI. Jakarta.

Sapto, Wahyu, 2012. Analisis Pengakuan Pendapatan dan Beban Kontrak pada UD. Gunawan Steel. Jurnal April 2012, Volume 12 Nomor 1. Sekolah Tinggi Ilmu Ekonomi Indonesia. Banjarmasin. http://jurnalstieikayutangi.ac.id/berita-194-analisis-pengakuan-pendapatan-dan-beban-kontrak-pada-ud-gunawan-steel.html.

Diakses Agustus, 12, 2013.

Nilam Venty Isabela, 2012. Analisis Akuntansi Atas Pendapatan Dan Biaya pada PT Bangun Energi Di Samarinda.

Muhammad Enstein Widodo, 2012. Analisis Penerapan PSAK 34 (Revisi 2010) Atas Pengakuan Pendapatan dan biaya pada PT. IKPT 